JOURNAL OF EDUCATIONAL REVIEW AND RESEARCH

e-ISSN: 2597-9752 dan p-ISSN: 2597-9760

This work is licensed under

a Creative Commons Attribution-NonCommercial 4.0 International License.

\title{
Writing Workshop: The Author Character Training Strategy
}

\author{
Ahmad Ridhani \\ Mulawarman University \\ ridhaniahmad16@gmail.com
}

\section{Keywords : \\ Writing workshop, character} education, independence

\begin{abstract}
The activity of writing is indispensable in everyday life, both in the life of society and in academic life. The life of the society marked the existence of communication through writing or writing manual recording via social media. The activities of the academic life were marked in writing the existence of communication in various academic activities. Write various documents required as evidence of the existence of an activity that can be accounted for. writing workshop project (WWP) aims to train skills and writing skills, and develop the character of the author. Abilities and writing skills include: (1) the ability to use the techniques and are assigned grammatical the writing; (2) choice of words; and (3) the ability of arguing. The construction and development of the author's character is closely related to (1) the ability of thinking ability, (2) reasoning, (3) academic ability, social abilities (4), (5) emotional ability, and (6) the ability of aesthetics.
\end{abstract}

\section{INTRODUCTION}

Study on the fact is the process of interaction of all the existing situation around students. Learning can be viewed as a process that is directed toward the purpose and process of doing through a variety of experiences. Learning is also a process of seeing, observing, and understand something (Sudjana, 2010) Learning Activities carried out by the teachers and professors. Learning behavior is an effort learning pupils (Degeng, 2013). Learning behavior is closely related to the use of the approach and model of learning which gives the opportunity to students to be active and creative in learning.

The process of active and creative learning opportunities to teachers, professors, students, and students learning to do it democratically. The students and the students are given the opportunity to develop all the existence of potential for it to be existencly in everyday life. Students who are active students are able to search and find themselves through direct experience are contextually, namely by way of explore and elaborate on their learning experience. Creative students are students that are able to harness and create opportunities and appreciated by people who are in the vicinity.

The activity of writing is indispensable in everyday life, both in the life of society and in the lives of academic. The life of the society marked the existence of communication through writing or writing manual recording via social media. The activities of the academic life was marked in writing the existence of communication in various academic activities. Write various documents required as evidence of the existence of an activity that can be accounted for.

Learning to write is aimed so that the author can convey thoughts, ideas, and feelings to the reader are written. The writer communicates with the reader by making use of the argument so that the 
information presented can be understood and understandable by readers. The argument is a set of statements in the form of the establishment of and support for the statements that appear (Warnick and Inc., 1994). The argument used to influence others in order to approve it.

Disclosure of the mind in a discourse written, among others, are characterized by the presence of arguments that can be sustained accuracy and truth (Warnick and Inc., 1994, Dawud, 2010, and Ridhani, 2012). The quality of the argument depends on the quality of a proposition which is maintained or confirmed as well as the quality of the evidence used to support the proposition. The relationship between proposition and proof evidence put forth largely determine the quality of the arguments put forth by a argumenter. In other words, the argument as reflected on the ability of connecting the proposition and the evidence put forward to convince others appropriately and correctly.

Disclosure of thoughts, ideas, and feelings to the reader is done through writing workshop project (WWP). Writing workshop project trained to writing skills, writing skills, character development author. Writing ability is closely related to the ability to master technical writing and the ability to argue. Ability to master technical writing focuses on the use of spelling and punctuation. The ability of the existence of marked ability mengungkapkanpikiran argued, ideas, and feelings of a person to the reader correctly.

Writing is a skill used language to communicate indirectly, not face-to-face with other people. Writing is an activity that is productive and expressive. In the activity of writing, writers must be skilled at harnessing the words, structure, and vocabulary. Writing skills will not come automatically, but have to go through the exercises and practice a lot and regularly.

\section{METHOD}

Writing skills desperately needed in modern life. Writing skills is a hallmark of the people who are literate or educated nation. A writer can write activity to report, inform, and influence the reader to follow what he wrote. Such goals can only be achieved by people who can sort ideas, thoughts, and perasannya with a clear businesslike. Clarity and logical proposition submitted depends on the mind, are assigned grammatical, structure of ideas, and the choice of words used.

Writing workshop project also aims to train, build, and develop the character of the author. Training, coaching, and development of the author's character requires planning, implementation, and evaluation of specific and ongoing. Training, coaching, author and character development is closely related to (1) critical thinking ability, (2) the ability of working together, (3) confidence, self-reliance and (4). Paradigm against writing is closely related to (1) writing as a process, (2) writing is easy, and (3) writing is fun.

\section{RESULTS AND DISCUSSIONS}

\section{Character education for authors}

Education culture and national character is done through the educational values or virtues that became the basic values of the culture and national character (Zakiyah and Rusdiyana, 2014). Virtue became the attribute of a character is essentially a value. Therefore, education culture and national character is basically the development of values that are derived from the philosophy of life or an ideology of Indonesian, religion, culture, and values in the national education goals.

The character is a way of thinking and behaving for a living and working together, both within the sphere of family, community, nation, and is something that is typical of every individual (Samani, 2012). Utami (2015) also stated that the character is the quality or strength of the mental or moral, 
morals or character of an individual, which is a special personality that become the catalyst or movers, as well as distinguishing between the other individual. A person can be said to be characteristic in that person has been able to absorb the values and beliefs that are desired by society, as well as used to sebaagai the moral force of his life (Hidayatullah, 2010).

Good character is something that is desirable for the nation. Philosophers Aristotelis (Lickona, 2013) defined good character as living with the correct behavior, correct behaviour relate to others and connect with yourself. Good character consists of (1) find out the good, (2) wants the good, and (3) do yourself a favor (i), (ii) the habit of the heart, as well as (iii) the custom action. Kindness is a major key in character education. The goodness of heart and deed harmonised and balanced in our daily lives.

Character education is education that emphasizes the importance of educational manners at home, at school, and in the community. Character education according to Aqib (2012) is a system of cultivation of the values of behaviour (character) in school which include knowledge, awareness or willingness, and actions to implement the values, either to the one true God, yourself, others, the environment, as well as the nationality thus becoming in goodness human.

Character education a universal context, emerging and evolving based on by the thought that the school is not only responsible for the learners to be intelligent, but also have to take responsibility to empower themselves so that have moral values integrated everyday life. The school facilitates the construction and development of character education and followed or are aligned with and support the behaviour of families and communities.

One of the keys to the success of character development in the education unit is the example and conditioning from teachers, lecturers, and produce educators keteladan rather than simply an example for the students, but also as a moral booster for the pupils and students in being and behaving. Example reflected in the patterns and behavior of the teacher or lecturer who can emulate agardan dipedomani by pupils and students in the context of learning. Conditioning is reflected in the implementation of consistent and responsible for the existence of the character education at school, at home and in the community.

The formation of the character of the author is done through three dimensions, namely the creation of the character of the author at (1) moral knowledge level, (2) the moral feelings of landscape, and (3) moral behavior level. The formation of moral character of writer knowledge level can be done by presenting a variety of moral values that are owned by the author and the paper product. Moral value embodied in the minds, attitudes, words, and deeds of a the author of implemention a paper based on religious norms, laws, manners, customs, culture, and ethics. A number of propositions presented to the reader the moral value of what's more nuanced moral values of Pancasila.

The formation of character writer in morallevel is presentedthe author feeling when making observations and actions by interacting and communicating with nature, society, and culture. Writer to interaction and communicate with nature and the natural environment embodied in proposition proposition containing the outpouring of hearts or the scream of nature; maintenance, and preservation of nature, human concern towards nature and the natural environment.

Writer to interaction and communicate with the community and the social environment is manifested in sentences containing the protests, anger, injustice, greed, social dominance, sexual abuse, crime, social as well as a commendable effort do a person or a group of people to goodness and charity of worship for the sake of family, community, nation, and world.

Writer to interaction and communicate with culture and claws culture manifested in sentences containing the history, description, narration, persuasion, argumentation, exploration, exploitation, cultural preservation, and maintenance of cultural heritage, both reserve the culture of local, regional, 
national, and international. The author attempts to expose a variety of facts, data, opinions, sketches, drawings, samples, models, and various upayaagar can be read and understood by the public at large.

The formation of character writer in morallevel is presentedtobehavior of interacting and communicating with (1) the nature and the natural environment; (2) community and social environment, (3) culture and heritage in the budayayang realized in the sentences contain notices, description, naration, explanations, and moral behavior modeling so that readers can get information about (i) the nature and the natural environment; (ii) community and social environment, (iii) the culture and heritage in a comprehensive manner.

\section{Writing as a process}

The activity of writing as a process means that writing includes a series of activities that occur repeatedly. Murray (1985) stated the three stages of writing, rehearsing, i.e. pengedrafan, and revision. The complete, Ellis (1989) and Tompkins (1994) outlines five stages of writing, namely prewriting, drafting, revising, editing, and publication. On stage prewriting, authors prepare to write. Activities focused on the theme of the essay or problem selected. Based on the theme of the essay or problem defined topics and types of writing, and a frame of wreath.

The writing of the draft is the activity of putting together a bouquet of intact (Suparno and Jonah, 2002). The writing of a draft that is the process of disclosure of the details of the idea that is already arranged in hierarchical and systematic. Setup details of hierarchical notion to put nature of relationships intercomponenwritings. Structuring details or equivalent multilevel antarkomponen idea in an exposure. Setup the details of the idea of systematically to maintain the regularity of intercomponen. Regularity in the essay looks at the pattern of reasoning, accuracy, completeness, and integrated relationship intercomponenthe idea.

Revising and editing is done after drafting is considered complete. Activities focusing on the examination and repair of the contents of the essay. Author writing drafts back read, change, or remove words that fit better, or eliminating redundant phrases. Zimmerman and Kitsantas (1999) states that have the ability to fabricate it takes a long process, a lot of practice, a lot of correction or improvement. The author had the opportunity to read and re-arrange the ideas that have been compiled. The author interacts directly with the text that has been worked on. Repeatedly read, pay attention to the writings of, and dialogue with yourself about what is and is not yet described in their writings.

Focus of editing on mechanical aspects. The author the opportunity to notice and identify the writing mistakes. Aspects of it in the form of writing capital letters, writing of pronouns or prepositions, Word breaks and punctuation appropriately.

Publication stage is done after the bouquet is thoroughly done. Authors can submit writings to the editors of magazines, newspapers, or journals for publication. If the writing in the form of recommendations can be delivered to the desired party.

\section{Writing Workshop}

Writing workshop aims to encourage, facilitate, and actualize themselves in writing as a necessity. Writing activities have not yet become a necessity good everyone, including lecturers, teachers, students, students, as well as other personal. It is seen in the lack of lecturers scientific publications in the form of books, articles, papers, and paper lainnyadi public and private colleges, as well as in the community.

Writing workshop gave an opportunity to academics, practitioners, and other learning communities to convey his ideas in writing and ongoing. Submission of ideas through writing discourse demands a 
certain amount of willingness and ability to perform the activity of writing. Willingness and ability to write as a necessity can be drilled.

Training activities of writing as a necessity to do so created the community learn consciously writing. Writing as a requirement can be implemented if undertaken with great seriousness and responsibility. Writing workshop project is done in programmatic and ongoing. Training and learning strategy is carried out through individual and group assignments, discussion techniques, journal writing, journal, conference and dialogue writing. The trainees were facilitated for publicated their writes through journals, e-journal, and book.

Writing workshop aims to train skills and writing skills as well as build the character of the author. Writing abilities and skills training focused on: (1) the ability to use the techniques and are assigned grammatical the writing; (2) choice of words; and (3) the ability of arguing. The construction of the characters the author focuses on (1) critical thinking ability, (2) the ability of working together, (3) confidence, self-reliance and (4). Writing workshop project goals are presented here.

\section{Training skills and writing skills}

Abilities and writing skills training focuses on the ability of (1) using the technique are assigned grammatical and writing; (2) choice of words; and (3) the ability of arguing. Abilities and writing skills presented here.The ability to use the techniques of writing,spelling, and punctuation. Spelling is a set of rules on how to write the language using letters, words, and punctuation as proximity. Spelling is a set of rules on how to write the language using letters, words, and punctuation as proximity. Punctuation that marks a readings. Hence, a punctuation mark written sticking with marked, both before and afterwards.

The use of writing gramatical focusing on: words, phrases, clause, sentence, paragraph, and discourse. The use of writing gramatical in the Word looks at the ability of the author to choose and sort out the word and the term with the title of writings. The word is component of written or spoken language which is the manifestation of the unity of the feelings and thoughts that can be used in the language. Termconsist of words or combined words carefully to reveal the meaning of the concept, process, the typical properties in a particular field.

The use of writing gramatical of phrases appears on the ability of the author to use the phrases in his writing. The phrase is a syntactic construction that consists of two or more words yet are predicative (no structured $\mathrm{S}$ and $\mathrm{P}$ ).Are assigned grammatical usage in writing clause appears on the ability of the author to use the clause in his writing. The clause is a syntactic construction that has a predicative. Clause ituunsur-forming sentences.

The use of the writing gramatical of sentance appears on the ability of the author to use a number of sentences in his writing. The sentence analyzed based on clause consists of a single compound sentence and sentence. Single sentence consists of a single clause. Compound sentence consists of two or more clauses.

The use of writing gramatical in the paragraph appears on the ability of the author to use a number of sentences in a paragraph. Spring (1990) States that a good paragraph is a paragraph that has a 
requirement, namely (1) the unity; (2) coherence; (3) adequacy; and (4) patterned arrangement. Unity means that all sentences that build the paragraph only States or discuss the same thing. The coherence or the statement, this means that each sentence has a reciprocal relationship is good and regular. Adequacy of development, that is to say a main idea developed or explained to taste thus achieved the goal of clarity theme staple. In this case it certainly isn't required the presence of the excess of the explanatory sentence so arise the impression of rambling, or too short so that it has not yet reached the level of clarity. Patterned arrangement, meaning that ideas or topics are arranged in a pattern of good order, chronological order, what is the arrangement of space, or the logical order, so that it is capable of showing the unity or coherence.

The integrity of a paragraph can be measured from two things, namely the cohesion and coherence. Cohesion is a semantic concept referring to the grammatical elements in the docking between a writing by using a formal liaison, i.e. any cohesion. Other aspects distinguished from grammatical cohesion and lexical. Grammatical aspect of the discourse, includes: (1) reference, (2) substitution, (3) ellepsis, and (4) arranging (conjunction).Lexical aspect or lexical cohesion in discourse is antarunsur in semantic difference (Sumarlam, 2003). Lexical aspect in discourse are distinguished into six kinds, namely: (1) repetition, (2) indeterminate words (sinonimi) collocation, (3), (4) antonym, hiponimi, (5) and (6) of metonymy.

The use of writing gramatical on the level of discourse. The discourse is the most complete linguistic unit. A form of discourse can be words, phrases, clauses, sentences, and paragraphs. This type of discourse includes oral discourse and discourse. Oral discourse, e.g. a conversation and the implementation of the live broadcast. Written discourse can the form of words, phrases, clauses, sentences, and paragraphs. All of the criteria in effect at words, phrases, clauses, sentences, and paragraphs, also applies on a discourse.

The ability of the use of the word choice seems on the writing produced by the author. The choice of Word or diction is basically an attempt choosing the words to get the final result in the form of a specific word (elected) to use in a speech language (Finoza, 2001). Word choice is done if possible a number of Allied word meaning equal or bermiripan can be used in a sentence. From seranai it will choose one word that was considered most appropriate to express a sense, either as a word (meaning of words) as well as to build the meaning in a sentence.

The ability of the author argues the proposition appears on the propositions presented authors in a discourse of academic writing. propositions that were presented in the form of establishment, proof, and a false assertion (Ridhani, 2012). The quality of the argument depends on the quality of a proposition which is maintained or confirmed as well as the quality of the evidence used to support the proposition. The relationship between proposition and proof evidence put forth largely determine the quality of the arguments advanced by an author (Warnick and Inc., 1994, 2010, Dawud, and Ridhani, 2012).

Establishment as part of an element of arguments is the opinion or conclusions drawn based on the evidence, guarantee, suppositions, and rebuttal. There are a few words or groups of words that indicate an establishment, among them so, therefore, thus, and simpulannya. That is, the proposition after the markers is the establishment. Use the markers on the argument makes it easy for readers to find the position defended by the author. In fact, Santoso (1995) suggested a good reasoning attempted to cite markers were explicitly so that the reader easily understand written by authors through markers (including markers of the reasons).

Proof is the nucleus for a discourse write because of proof can provide facts or reason to make an opinion or opinions (Ridhani, 2012). Substantiation for the writer is to show to the reader that this evidence supports the arguments written. When the author introduces or show proof, then the author should indicate to readers why this evidence supports an argument. This evidence must be analyzed and interpreted. With an argument, proving to be powerful and could be used to take a decision. 
False assertion is the process of getting a proposition drawn from one or more propositions (Mehra and Burhan, 1988 and Ridhani, 2012). False assertion made on more than one proposition and if expressed in a language called argument. Furthermore explained that false assertion in General conducted in inductive and deductive. A false assertion of deductive, summary not may be more common than its premises while the inductive basis, the conclusion is certainly more common than its premises. Deductive false assertion may be made directly or indirectly. False assertion directly is a deductive process simpulannya was withdrawn from one premise alone, whereas indirect conclusions are conclusions drawn from two or more premises.

Coaching character of writer which can be nurtured and developed in the workshops of writing is closely related to (1) the ability of thinking ability, (2) reasoning, (3) academic ability, (4) social abilities , (5) emotional ability, and (6) the ability of aesthetics. A number of the characters in the following explanation.

The character of writer thinking ability is owned and developed through the workshop to write, for example: write a discourse arguing, making financial statements, reporting the results of analysis of the data, and the like. The thinking ability of characters appears on the proposition of propositions which are written in the discourse of academic writing.

Character of writer rasioning ability isowned and developed through the workshop to write, for example: when the author wrote the narrative discourse, discourse writing descriptions, or write a discourse of persuasion, authors can connect one proposition with the other proposition. A proposition of writer showing the existence of the interconnectedness of the topic so that the academic discourse produced.

Character of writer academic discourse abilitiyis owned and developed through the workshop to write, for example: when a writer writes proposals, research writing research reports, thesis writing, writing a thesis, or dissertation writing, the author is able to (i) writing by using the spelling and punctuation are correct; (ii) use the appropriate word choice; (iii) composing the sentence intact; (iv) drawing up a cohesive and coherent paragraphs; and (v) write a discourse. The writing activities can be understood or analyzed by observing the simple proposition that appears, in the form of (i), (ii) phrases, clauses (iii), (iv), (v) sentence paragraphs, and (vi) discourse.

Social intelligence characters owned by penulisdibina and developed through the workshop to write, for example: when a writer to write a descriptive narrative discourse or discourse, the author reveals the thoughts, ideas, and feelings related phenomena and behaviors social surroundings. What is seen? What is heard? What is the record? What do I do? What is perceived? What is thought? Everything can be made into Materials or materials writing.

The character's emotional intelligence penulis di bina owned and developed through the workshop to write, for example: when the author wrote a discourse of persuasion, he makes the discourse of advertising. The discourse that he should reflect the emotional intelligence. Sentences that contain the anger, resentment, confusion, carelessness, nervousness, and the like should not be featured. The choice of words used themed persuasion. Sentences that contain praise, excess, effectiveness, and the like are presented straightforwardly.

Aesthetic intelligence characters owned by the author through the writing workshop, for example: when the author writes expressive discourse, he very intelligently choose word choice aesthetics. Sentences that contain charming, pretty, graceful, thoughtful, hospitality, and the like are presented with the grammatical meaning of the charge and denonatif. 


\section{CONCLUSION AND SUGGESTION}

Disclosure of thoughts, ideas, and feelings to the reader in tulisdapat performed through Writing workshop project. Writing workshop project is trained abilities and writing skills, as well as the construction and development of the character of the author. Writing ability is closely related to the ability to master the techniques of writing and the ability to argue. The ability to master the techniques of writing focuses on the use of spelling and punctuation. The ability of the existence of marked ability of argued, ideas, and feelings of a person to the reader correctly. The ability of the author argues the proposition appears on the propositions presented authors in a discourse of academic writing that is written. propositions-propositions that were presented in the form of establishment, proof, and a false assertion. The quality of the argument depends on the quality of a proposition which is maintained or confirmed as well as the quality of the evidence used to support the proposition. The relationship between proposition and proof evidence put forth largely determine the quality of the arguments advanced by an author. The construction and development of the character of the author in writing workshop focused on coaching and character development that are related to (1) the ability of thinking ability, (2) raisoning, (3) academic ability, social abilities (4), (5) capability emotional, and (6) the ability of aesthetics. A number of the characters mampudibina and developed activities in the workshops of writing so that the author was able to write with the writings reflect character in accordance with the process and the results desired.

\section{REFERENCES}

Abidin, Yunus. Pembelajaran Membaca Berbasis Pendidikan Karakter. Bandung: Refika Aditama.

Amri, Sofan. (2013). Pengembangan dan Model Pembelajaran dalam Kurikulum 2013. Jakarta: Prestasi Pustaka.

Aqib, Zainal. (2010). Pendidikan Karakter Membangun Karakter dan Kepribadian Anak. Bandung: Yamma Widya.

Dawud. (1998). Penalaran pada Tuturan Bahasa Indonesia Siswa Sekolah Dasar. Disertasi tidak diterbitkan. Malang: IKIP Malang.

Degeng, Nyoman, S. (2013). Ilmu Pembelajaran: Klasifikasi Variabel untuk Pengembangan Teori dan Penelitian. Bandung: Kalam Hidup.

Ellis, A.; Pennau, J.; Standal, T.; and Rummel, M.K. (1989). Elementary Language Arts Instruction. Englewood Cliffs: Prentice Hall.

Faturrohman, Pupuh; Suryana, AA; Fatriany, Fenny. (2013). PengembanganPendidikan Karakter. Bandung: Refika Aditama.

Hidayatullah, M. Furqon. (2010). Pendidikan Karakter: Membangun Pradaban Bangsa. Surakarta: Yuma Perkasa.

Kementerian Pendidikan Nasional, Badan Penelitian dan Pengembangan Pusat Kurikulum. (2010). Pengembangan Pendidikan Budaya dan Karakter Bangsa. Jakarta: Kemendiknas.

Lickona, Thomas. (2013). Pendidikan Karakter Panduan Lengkap Mendidik Siswa menjadi Pintar dan Baik. Bandung: Nusa Media.

Murray, D.M. (1980). Writing is Process: How Writing Finds Its Own Meaning. Dalam Donovan, T.R. dan McClelland, B.W. (Eds.), Eight Approaches to Teaching Composition (hlm. 3-20). Illionis: National Council Teachers of English.

Ridhani, Ahmad. (2012). Wacana Tulis Argumentasi. Malang: UM Press.

Utami, Diyah, Ratnasari. (2015). Membangun Karakter Siswa Pendidikan Dasar Muhammadiyah melalui Identifikasi Implementasi Pendidikan Karakter di Sekolah. Jurnal Profesi Pendidikan Dasar Vol. 2. No. 1 Juli 2015: 32-40).

Samani, Muchlas dan Hariyanto. (2014). Pendidikan Karakter: Konsep dan Model. Bandung: Remaja Remaja Rosdakarya.

Sudjana, Nana. (2010). Penilaian Hasil Proses Belajar. Bandung: Remaja Rusdakarya.

Tompkins, G.E. (1994). Teaching Writing Balancing Process and Product. New York: Macmillan College Publishing Company. 
Warnick, B. dan Inch, E.S. (1994). Critical Thinking and Communication. New York: Macmillan Publishing Company.

Zakiyah, Yuliati, Kiki dan Rusdiana, A. (2014). Pendidikan Nilai: Teori dan Praktik di Sekolah. Bandung: Pustaka Setia.

Zubaidi. (2011). Desain Pendidikan Karakter; Konsepsi dan Aplikasinya dalam Lembaga Pendidikan. Jakarta: Kencana Pranada Media Group. 